\title{
Ottoman Empire
}

\author{
Elena Marushiakova and Vesselin Popov
}

\subsection{Introduction}

The beginnings of Romani literature and media in the Balkans, in the conditions of the Ottoman Empire, can only be properly understood and explained when placed in the general context of the birth and development of the movement for Roma civic emancipation during the modern era. There is an interesting particularity of this movement, which takes different forms and directions, conditioned by the specific context in the different regions of this multinational Empire. In some cases, this movement (and, accordingly, Romani literature and press) are closely linked to the national liberation struggles of the Balkan Orthodox peoples (among Roma Christians) and, in other cases, it is part of the general development of the Ottoman society (among Roma Muslims).

The reasons for this division can be found when looking at the overall situation of the Ottoman Empire and the place of the Roma in its socio-political structure. Here, the so-called 'Gypsies', whose official name in Ottoman-Turkish was Kıptı (i.e. Copts - the native Egyptians) or Çingene, were full-fledged subjects of the Sultan (i.e. citizens of the Empire) and, unlike the Gypsies in Central and Western Europe who achieved this social status much later, had had civil rights since the fifteenth century (Marushiakova and Popov 2001). However, the population in the Ottoman Empire was not in an equal social position, as the main division was into two basic categories, distinguished according to their religion - orthodox (Muslim) and infidels (non-Muslims).

Gypsies, who were separated by ethnicity in Ottoman law (a relatively rare phenomenon for this Empire), fell into both categories according to their religion (Muslims or Christians), which in turn predetermined the development of Roma civic emancipation in two main directions and, along with this, it flew in different forms.

\subsection{Roma Christians}

In 1867, the Bulgarian newspaper Macedonia, printed in Istanbul, published a reader's "Letter to the Editor" (the chief editor was Petko Rachov Slaveykov, a renowned Bulgarian enlightener, fighter for civic and national revival of Bulgarians and for the independent Bulgarian church); the letter was signed with the pseudonym "One Egyptian" (Един Егюптиянин 1867:3; for full text of the letter see Marushiakova and Popov 1995:39-42;

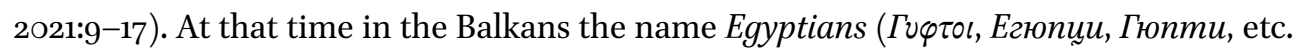


in the various languages) designated Gypsies, which, in the Ottoman Empire, referred to their official name Kıptı (meaning Egyptians), and which in turn originated from

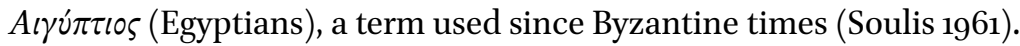

This "Letter to the Editor" in the newspaper Macedonia represented a direct response to the editor of the newspaper - Petko R. Slaveykov and his article entitled "The Gypsies," published in Gayda newspaper in 1866 (Славейков 1866:256-258) and which actually inspired the author of the letter to write it. In this article, the leading discourse was the origin and history of the Gypsies in the Balkans, to where, according to its author, they migrated from Egypt; moreover, the Gypsies were said to be those who brough to the "wild" Greeks the benefits of civilisation, as evidenced by the borrowings from their language in Greek (Един Егюптиянин 1867:3). The 'evidence' of the origin and history of the Gypsies presented in this article is undoubtedly original (or, rather, even extravagant), although far from the achievements of European science at the time. The 'Egyptian' hypothesis about the origin of the Gypsies, especially popular in the Middle Ages, was, at the time, long overdue in the history of science; however, in the Balkans, it unexpectedly found its new life. The reasons for this are rather socio-political - this was the height of the struggle for independence of the Bulgarian church against the Greeks, and the humiliation of Greek's ancient history was part of the arguments in this struggle, of which Petko R. Slaveykov himself was one of the leading figures.

In this context, the author of the "Letter to the Editor" in the newspaper Macedonia used the article by Petko R. Slaveykov as a starting point for presenting the contemporary problems that his community faced, namely the need for religious emancipation of the Gypsies, which for him constituted an integral and important part of their overall civic emancipation.

Summing up the "Letter from One Egyptian": it was directed against the Greeks, because, according to the author, they were to blame for the plight of Egyptians and a major obstacle to their civic development. In particular, the letter opposed the overall management of the Orthodox Church by the Greek church elite, in the conditions of the Ottoman Empire. This elite was called Phanariotes, from the name of the neighbourhood Phanar (modern Fener) in Istanbul, where the court of the Patriarch resided, and rich Greek merchants lived, who influenced the Ottoman administration. The Greek church elite under the Ottoman system was recognised as both the spiritual and secular head of all the Orthodox subjects of the Empire (except those Orthodox who were under the spiritual care of the Patriarchs of Antioch, Jerusalem and Alexandria). The Phanariotes were accused of not allowing other Orthodox nations in the Ottoman Empire, as in the case of Bulgarians, to have religious independence. In the words of the author: "the Phanariotes govern our faith" and were insisting that "only they have the right to it and only they are followers of the Apostles of Christ" (Един Егюптиянин 1867:3).

In his letter, "One Egyptian" argued that the policy of the Greek Church is detrimental to all nations, but most severely affects the Egyptians, who were not allowed into the Orthodox Church. With many quotations from the Holy Scripture, the author of the 
letter argued that the Greeks had no reason for such an attitude towards the Egyptians. Christianity does not divide different peoples into those "chosen by God" and those "unpleasant to God," because all people are equal before God, including the "Egyptians" who are also entitled to have their own "spiritual education" (Един Егюптиянин 1867:3). Greeks were further blamed because they considered only themselves to be "pleasant to God, and all others consider suspicious and unworthy", and insisted that only their language was appropriate for worship and forgot that "the Apostles speak all languages through the Holy Ghost and not only the Hellenic" (ibid.).

According to the Letter, the Egyptians, historically, in their motherland of Egypt, had "reached a high degree [of] education [but] they did some disturbances in Egypt. From which some thousand [people] were displeased and moved to Hellas. There, in Hellas, they brought together with them their eternal arts and alphabet." (ibid.)

The author of the letter used arguments to plead for the right of the Egyptians as an ancient people. Along with this historical reasoning, the author of the letter also relied on the authority of the Holy Scriptures to present and defend the concept of the equality of his community:

... we see that it will all be in benefit to the Greeks regardless of who invented it and ordained it, they take it and do not let go, and all which is not in their benefit, that is which contradicts their lofty ideas and distinguishes all peoples in the Christian faith, though it was made legitimate by Jesus Christ himself and the Apostles who said - "There is neither Jew nor Greek, slave nor free, male or female, for you are all one in Christ Jesus" (3 Galatians; 28) they do not recognise it and pretend to be deaf as [if] they do not know it ... (ibid.)

In the text, "One Egyptian" did not limit himself to substantiating the right to religious emancipation of his community but also outlined the more distant goals and the next necessary steps for its overall civic emancipation. He wrote:

That same thing we saw in Gayda ... where proving about our origin that we are a breed of the old Egyptians, which is proved live not only by our advantage and abilities, but by our very language and the appellation "Egyptians" which we still hear today ... (ibid.)

Because of their glorious past, they have the right to have religious worship in their own language and to "create a society and take care of education" (ibid.). The letter ends with an appeal to the Greeks:

If they want to be proud before Europe that they are enlighteners, let them first bow and prostrate themselves at our feet, to recognise their enlighteners and do their duty with which to show a faithful example for the others, and then they would have the right to ask. (ibid.)

This letter can be properly understood only in the context of the social movement of Bulgarians against the Greek Patriarchate during this period, in an effort to have their 
'own' Bulgarian church. The newspaper Macedonia, where the previously discussed "Letter to the Editor" was published, was the main speaker for this movement, and its editor-in-chief, Petko R. Slaveykov, was one of its leaders. For the author of the letter, "One Egyptian", and similarly for the Bulgarian national revivalists, these 'church' struggles were religious only as a form, but in fact they were a movement for the protection of the fundamental rights of every nation to religious and civic equality respectively. The author felt the disparaging (in the best case) attitude of the macro-society towards Gypsies and suffered from the restrictions imposed on his people by the Christian (and in general the religious) institutions of that time. In his letter, he shows the injustice of such an attitude both in terms of the essence of the Christian religion and in terms of the historical fate of individual nations. In defence of his thesis about the "historical right" of the Egyptians to "create a society and [take] care of education" he uses the historical knowledge accessible to him (Един Егюптиянин 1867:3.). Apart from Scripture itself, which the author undoubtedly knew very well and repeatedly cited in his letter, in defence of his thesis, was the article written by Petko R. Slaveykov, discussed above, which was also the main (and, at the same, time, the only) source of information for him about the history of his community.

The content of the "Letter to the Editor" confirms once again what we know from other historical sources. In the Ottoman Empire, the Roma Christians were integrated into the social fabric with their own social and civil status, which was very similar to the status of other Christian nations' subjects of the Empire (Marushiakova and Popov 2001). As a result, the development of the Roma, at least on the level of ideas, was very similar to the development of the other Balkan nations among whom they lived. The letter shows that at least some members of the Roma community in the Balkans in the nineteenth century reached a new stage in the development of their nationality consciousness. This new stage is characterised by exiting the 'internal' traditional frames of their community in order to search for equal place in the new 'external' socio-cultural realities, according to the norms and values that predominate. It was the Balkan context that determined the shape of this new public appearance of Roma - they, like other Balkan nations, were searching actively for proof of a 'glorious' historical past. They were aiming for the creation of a new national historical mythology that would serve as support and argument in the struggles for their civic emancipation, as separate but equal to other Balkan nations' communities. As a whole, the logic of the Roma development, as seen in the "Letter to the Editor", is a repetition of the pattern of development of the other Balkan nations in the nineteenth century in all its segments - the creation of their own system of education, their own church with services in their own language, and eventually, without specifically mentioning it, the implied perspective of their own state.

The answer to the question who the "One Egyptian" was, we were able to find in the materials published by a famous folklorist from the end of the nineteenth century, Marko K. Tsepenkov. Describing the existing guilds in the town of Prilep (now in the Republic of North Macedonia), he noted the existence of separate Gypsy guilds 
(of blacksmiths, violinist and porters) with their respective Patron Saints' holidays St Athanasius and St Antonius (Цепенков 1898:180). The existence of ethnically distinct Gypsy guilds in the Ottoman Empire has been known since the first half of the seventeenth century, and it was preserved (in more or less modified forms) in the new independent states on the Balkans until the first decades of the twentieth century (Marushiakova nad Popov 2016:76-89). In the Balkans, as the Patron Saint of blacksmiths (by Gypsies and by the Christian majority as well), is honoured St Athanasius. As Marko Tsepenkov noted in the city of Prilep, the Patron feast of the local Bulgarian guild of blacksmiths was also on the day of St Athanasius (January 18), while the guild of "Gypsy blacksmiths" and the guilds of [Gypsy] "fiddlers and porters" (a separate ones) venerated St Antonius, which is on January 17 , i.e. demarcation of the guilds on ethnic lines was clearly visible also in this case (Цепенков 1898:181).

This development of the social life of the Gypsies in Prilep is explained by Marko Tsepenkov as follows:

The reason behind all this is a Gypsy called Iliya Naumchev, a barber. This Naumchev, to him went more educated people in his barber shop and day by day he advanced and accepted his ethnicity and he was not ashamed to call himself an 'Egyptian', because, as he explained, the name came from Egypt. This Iliya hoped very much for a priest of Gypsy ethnicity. Many years have passed, but he still desired to have this rank among them ... 2-3 years ago, he succeeded to become himself a priest in the Holy Exarchate. (Цепенков 1898:180-181)

A sufficient dose of confidence may suggest that this Iliya Naumchev is the "One Egyptian", who wrote the "Letter to the Editor" in the Macedonia newspaper. The dream expressed by Ilya Naumchev in his "Letter to the Editor" of the newspaper Macedonia, failed to materialise, and the independent Gypsy Orthodox Church for which he appealed was never created. This dream remained at the stage of a vision for future development, because there were no objective conditions for its realisation, and in the first place there was a lack of sufficient number of educated Roma elite among Roma Christians to prepare the masses and lead the struggle in this direction. The fight of Bulgarians for an independent Bulgarian Orthodox Church was more successful and, as a result, in 1870 the Bulgarian Exarchate was created with a Decree (Firman) of Sultan Abdulaziz. It granted the right to establish an autonomous Bulgarian Exarchate for these dioceses, wherein at least two-thirds of the Orthodox Christians were willing to join it. In the plebiscite of 1873 in the town of Prilep, more than two-thirds of the inhabitants of the city, including local Roma, declared their wish to belong to the Bulgarian Exarchate, which had been influenced also by Iliya Naumchev's enlightenment activities among them.

In the new conditions, in 1885 , Iliya Naumchev fulfilled his hope "for a priest of Gypsy ethnicity" (ibid.) as he received the post of an Orthodox priest in the Bulgarian Exarchate. This is not a retreat from the idea of creating a Gypsy Orthodox Church, but a new stage in its development, when the first stage (church independence from the Greek Patriarchate) had already passed and Iliya Naumchev gained a legal opportunity to work 
as a priest among his brothers. However, this was accompanied by some problems in his confirmation in the post (probably due to the unusualness of the case) by the head of the Bulgarian Church (Exarch Joseph I), who requested the explicit consent of the Bulgarian municipality in Prilep and the parishes of the future priest. Nevertheless, in the end, the issue was resolved positively (Кирил 1969:611). The latest historical evidence about Iliya Naumchev is from 1900, when he continued to be a priest in the Bulgarian Orthodox Church in his native town of Prilep (Кънчов 1900:124).

The presented materials, irrespective of how few they are, allow us to speak about Iliya Naumchev not only as one of the founders of the movement for Roma civic emancipation (Marushiakova and Popov 2017:33-38) but also of Romani literature and, more specifically, of the journalistic genre of engaged publicistic. In any case, the "Letter to the Editor" in the Macedonia newspaper, authored by Iliya Naumchev, is the first text by a Roma author to appear in the public print media.

\subsection{Roma Muslims}

Among Muslim Roma in the Balkans, another civic emancipation tendency emerged. Unlike Roma Christians, who fitted into the context of the national revival of their neighbouring Balkan Christian people, Roma Muslims remained in the general discourse of the social development of the Muslim population of the Ottoman Empire. This development led to the establishment of Turkey as a nation-state in early twentieth century (officially in 1923), starting with the so-called Young Turk Revolution (1908), and was characterised by a break with the Ottoman heritage and the replacement of Ottoman identity (closely linked to Muslim religious identity) with Turkish national identity. These common processes in the Empire also applied to other Muslim communities (e.g. the Arabs, Kurds Albanians, etc.). In this context, the Muslim Roma (or, at least, some of their representatives) were also trying to find ways for the civic emancipation of their community under new conditions. The expression of these aspirations was the emergence of the newspaper Laço, which can be described as the first newspaper written by the Roma without any support from 'external' factors (such as religious or state institutions) and their respective attempts to influence Roma communities.

Extremely little is known about the Laço newspaper. There is evidence of a preserved copy of it and our colleague Peter Bakker, to whom we owe our gratitude for turning our attention to the very existence of this newspaper, has been trying hard to locate it for many years, but to no avail. In fact, the only source about this newspaper is one short article written by Henri Bourgeois (1910:326-329), a renowned scholar of Oriental Studies who also worked in the field of Romani linguistics (Bourgeois 1911) with the impressive (and, at the same time, misleading) title Unjournale pseudo-tchingiané (A pseudo-Gypsy Journal). 
According to the description of Henri Bourgeois, the newspaper Laço (Good, in Romani language) was published in Edirne (today in Turkey) by Emin Resa (Bourgeois 1910:326). Two issues were printed; or, more precisely, two issues were known to Henri Bourgeois, as there may have been more. Each of them includes "eight pages, large in $-8^{\circ}$ " (ibid.:327). The issues are dated 6 and 12 Şubat, 1235 (ibid.:326); according to the Islamic calendar Rumi used at that time in this part of the Ottoman Empire; this means February 19 and February 25, 1910 (Koloğlu 1995:61-62).

It is not entirely clear in what language the newspaper was written. Judging by the fact that the Ottoman-Turkish version of the Arabic alphabet was used and that under the title "Lexicon of Latcho" there is a small Romani language (Tchinghiané) - Turkish dictionary of thirty-two words (Bourgeois 1910:327), it can be assumed that the language was mixed-Turkish using words and expressions in Romani language. This was not an unusual phenomenon among Muslim Roma in the Ottoman Empire; rather the opposite, it was a natural expression of the ongoing process of language change and the result of it nowadays can be seen in large parts of the Roma population in Turkey and the Balkans (Bulgaria, Greece, Northern Macedonia) who have Turkish as their mother tongue. Especially in Edirne, this process is clearly visible in the example of a poster with an invitation for the celebration of Gypsy holiday Kakava in Edirne, published in 1934 (already under the conditions of the new state of Turkey) (Şanlıer 2018; Marushiakova and Popov 2021a). Moreover, the next two, almost analogous, posters, dated 1948 and 1966 respectively, differ from the one from 1934 mainly by the reduction of Romani language words and expressions in the 1948 one and their almost final disappearance in the poster from 1966 (ibid.), i.e. these posters are a clear illustration of the process of language change and development. The final result of this development is that today, out of seven Gypsy neighbourhoods in Edirne, Romani language is only still spoken in two of them.

The title heading of the newspaper Laço defined it already in its first issue as a "Humorous newspaper published for the moment once a week, serving the interests of the fatherland and the Ottoman nation." In addition, the header of the first issue gave the following two lines "Be blessed a thousand times, $\mathrm{O}$ day that you rise with light and love! There is no longer any hostility, tyranny, or exit", which, according to Bourgeois was "obviously allusion to the recent Turkish freedom." In fact, this was a reference to the Young Turk Revolution which proclaimed new equality of separate nationalities, including Roma, as well as freedom for expression of their identity, language and culture and thus created euphoria in shaping the visions for their future (1910:327).

In the second issue, one can find a special explanation "Half of the net proceeds from the sale of this number will be paid for subscription for the national fleet" (Bourgeois 1910:326-329) and, in this way, the newspaper publicly demonstrated the civic national consciousness among the Roma in the Ottoman Empire. The newspaper also presents a short dictionary of the Romani language (ibid.), which shows that this national (Ottoman) civic identity did not conflict with the ethnic identity of the community. The newspaper 
also contains illustrations of a Gypsy blacksmith and of a tent in the background (ibid.), i.e. a national symbol (a characteristic of nascent nations) appears graphically. The transition of images of artifacts from everyday life in the field of national symbolism is a common phenomenon among numerous nationalities in many parts of the world. Especially in Edirne, on all of the above-mentioned poster-invitations for Kakava, the same drawing appears, in which, in the foreground, images of smithing tong, anvil, spade and cezve (a Turkish coffee pot) (Şanlıer 2018) are clearly demarcated; the same objects (as well as other objects used by blacksmiths or made by them) can be seen depicted on the preserved flags of the Gypsy guilds in the Balkans, the oldest of which dates from 1849, from Prizren, in Kosovo (Marushiakova and Popov 2016c:8o-81). The name of the celebration itself - Kakava literary means 'cauldron' in Romani language - in fact is the "Roma version" of one festivity with old historical roots among all Balkan peoples, which is celebrated by the Christian people in the Day of St George and bears his name, while among the Muslims it is celebrated under the name Hıdırlez (the day of the Muslim saints Hıdır and Ilyaz); among the Roma the celebration has respectively acquired distinctly ethnic characteristics of their biggest national celebration (for more details, see Marushiakova and Popov 2007:33-50, 2016b:47).

It is interesting to understand the reasons behind Henri Bourgeois's definition of Laço newspaper as "pseudo-tchinghiané" (Bourgeois 1910:326), i.e. pseudo-Gypsy. His reasons for this are purely linguistic, his main argument is that the spelling of the Roma words is erroneous and there are discrepancies with the texts of Alexander Paspati (1870, 1888). A separate question is whether Paspati's work, in this case, can be considered relevant at all, since his texts were recorded by his associates in various places and among different Roma communities in the Balkans. From this, according to us, it was undoubtedly under a wrong premise that he concluded that the newspaper was written by a non-Rom "tziganophile" (Gypsyphile), who conveyed incorrectly heard words from illiterate Roma (Bourgeois 1910:329). This is a typical example not only of a linguo-centrism but also of the orientalist approach of a Western author of that time (something common even nowadays), who cannot believe that literate Gypsies may even exist and that an educated Rom in the East, if there is such one, could even be a 'genuine Gypsy'. Moreover, this explanation is completely illogical, because it does not make it clear why it was necessary to publish a newspaper in a language that no one can read in the first place - not even the Roma who were entirely illiterate (according to Henri Bourgeois), nor their surrounding population, who naturally did not know the Romani language. From this point of view, it does not matter whether the Romani language which is used is a 'correct' one (according to Henri Bourgeois' criteria) or not. It is not logically justified to seek in the language used an answer to the question whether the newspaper is 'Gypsy' or 'pseudoGypsy.' Using Occam's razor, we can say that it is obvious that the Laço newspaper was a 'Gypsy' newspaper, and that is exactly how it was perceived by its contemporaries (Roma and non-Roma). In this context, there is no reason to blame the publisher of the newspaper Laço (and probably its chief editor) Emin Resa for being a non-Gypsy "tziganophile" 
(Bourgeois 1910:329). For us, the simplest (and most logical) explanation is that Emin Resa was a Rom by origin and identity, who wrote in the language he spoke, as did the other Roma in Edirne. It is too naive (and without knowledge of historical realities) to assume that there may have been an eccentric ethnic Turk who, out of love for the Gypsies, or to make a financial or any other profit, would decide to publish a newspaper to be distributed in the Gypsy mahala (i.e. an ethnic neighbourhood in the Ottoman Empire).

Unfortunately, nothing more is known about Emin Resa; it is only palpable that if he was able to publish a newspaper, he should have received a relatively good education. And, more importantly, this was not an extraordinary exception in his time, because publishing a newspaper implied the existence of a possible audience, i.e. of a certain number of Roma who would be able to read it. The presence of a certain strata of Muslim Roma in the Ottoman Empire, which possessed at least an initial level of literacy, clashes with the mainstream societal stereotypes (as we see with the example of Henri Bourgeois, occurring even in academia), but it should not cause surprise. As discussed above, the Gypsies have been full-fledged civic subjects of the Ottoman Empire since the fifteenth century and Roma Muslims, in particular, were fully entitled (and at least some of them had a real possibility, which is even more important) to use the educational institutions in the empire. As an example in this regard, we can quote the request from 1693 to the court in Sarajevo, from the Gypsy baker Selim, a son of Osman, who explicitly wrote: "[I] send my children to the religious school to learn the Koran along with the rest of the children" (Marushiakova and Popov 2001:39). And, something more, in the nineteenth century, after the Russo-Turkish War of $1877-1878$, as part of the attempt to modernise the Ottoman state, Sultan Abdul Hamid II pursued a policy of pan-Islamism aimed at uniting all Muslims in the Empire. In the frames of this aim, special measures to ensure that the Gypsies learned their Muslim religion in a proper way were also developed and implemented. Along with this creation of an own network of primary schools (mekatib-i iptidaiye) and industrial high schools (medaris-i sanai) aimed at the Muslim populace, with Islamic content and curriculum, where Ottoman Turkish was used as a medium of instruction, Sultan Abdul Hamid II countered the foreign (mostly American) mission schools (Ümit 2014:33).

In this way, many religious schools were also opened to provide education to Gypsies in different regions of the Balkans. In order not to lose the Muslim population to their neighbouring countries, recently separated from the empire, the opening of such schools was also carried out in Bulgaria, Serbia, Montenegro, Greece, and Romania (Ulsoy 2013:94-98). In addition to these, the Gypsies who were enlisted in the army were also provided with basic education. In this sense, the presence of a sufficient number of literate Roma in Edirne, to whom the Laço newspaper was directed, is undisputed.

A statement that some of the profits from the Laço newspaper would be donated to the Navy was not just a gesture aimed at ensuring the authorities' favourable treatment of the newspaper and its readers. Gypsies had their place in the military structure of the early Ottoman Empire, and even in the sixteenth century there was a special non-territorial 
military-administrative unit, the so-called "Gypsy sancak" with its centre Kurklareli in Eastern Thrace (Marushiakova and Popov 2001:26-27). Gradually, over the centuries (and especially after the seventeenth century), Gypsies, for the most part, dropped out of joining the army; however, in the early nineteenth century, as part of the empire's reform efforts, the old Ottoman army was replaced by a regular army and general military conscription. Only non-Muslims and Gypsies, regardless of their religion, who were required to pay a special army tax (bedel-i askerii), were exempted from military service (Ulusoy 2013:50). This was perceived by many Muslim Gypsies as a restriction of their civil rights and placing them at a disadvantageous position. Evidence of this are the numerous petitions from settled Muslim Gypsies, preserved in the Ottoman archives, in which they demand to be allowed to serve in the army. One of the best known such petition was addressed to the wăli (governor) of Edirne in 1870. Finally, in 1873 this restriction for serving in the army of Muslim Gypsies was lifted (Ulusoy 2013:55-57).

It is not clear how long the Laço newspaper carried on, but we can suppose, from the fact that the newspaper is almost unknown, that its existence was only short-lived. However, we can assume that it had an impact on the Roma in Edirne and left its traces among them. The reason for such an assumption is the description of the language used in the Laço and the graphic symbolism of the newspaper, which is also (albeit different, but with some common elements) present later in the State of Turkey in the abovementioned posters for the celebration of the Kakava holiday published in the same city, Edirne, in 1934, 1948 and 1966 (Şanlıer 2018). It turns out that the presence of written communications, which included individual words or sections in the Romani language, and which were publicly presented in different forms, was nothing unusual for Roma living in Edirne at that time. It should be mentioned that these posters ceased to be produced in the last decades of the twentieth century, and nowadays the celebration of Kakava holiday in Edirne by local Roma was transformed into a major city holiday and even into a major tourist attraction for the city (Marushiakova and Popov 2007).

As noted by Henri Bourgeois (1910), at least half of the pages of the newspaper are devoted to humorous dialogues of two characters, Latcho (a Rom) and Mitcho (a Non-Rom). Most probably, this is a kind of reproduction through other expressive forms of plots from the then-popular shadow theatre, with the main character Karagöz (And 1975; Sennur 2004). According to many authors, Karagöz has been a real personality, who revamped the traditional theatre of shadows (that is why, often the theatre itself is named after him). According to Evliya Çelebi, Karagöz was born in Kırklareli and his father was a "fukara-i-kıbtiyan" (a poor Gypsy) (Çelebi 1967:20-23). According to others, Karagöz was a Turkish Gypsy who was taken as a soldier (Menzel 1941:56), who described himself as a Gypsy and who, in dialogue with Hacivat, explicitly said that he would never give up his "Gypsyness" (Prokosch 2002:103-129). Karagöz himself sometimes came on stage with a greeting in "Gypsy language 'Zombornos keros" and performed a blacksmith's trade (Jacob 1925:109). In other words, here also, as well as in the above-mentioned example 
concerning the importance of the blacksmith trade for the Gypsies, this is presented as a symbolic sign of their ethnicity.

Today, a monument for Karagöz has been raised in the town of Kırklareli in Eastern Thrace (in the region of Edirne) where Kakava is proclaimed as an official city holiday, and where a legend is commonly told nowadays among the local Gypsies, that Karagöz had been born in the nearby small town of Demirköy (Marushiakova and Popov 2007:43). Among other things, the theatre of shadows itself, often called 'Karagöz', is already just a memory of the past in present-day Turkey. Probably the only place where the traditional theatre of shadows has been preserved until present-day, is among the Gypsies of Western Thrace (in Greece), and one of the first books, published in Romani language in contemporary Greece, is dedicated to Karagöz. The book includes texts of a few scenes from the repertory of this theatre $(\Lambda \iota \alpha \dot{\pi}\rceil \varsigma$ 1996).

\subsection{Conclusion}

As is clear from all of the above, the emergence of Romani literature and press, as well as the beginning of the movement for comprehensive civic emancipation of the Roma in the Ottoman Empire, is a general historical process. The fact that in the first stages this development took place 'on two tracks' (Christian Roma and Muslim Roma) does not cancel its unity and the commonality of its pursued goals. Moreover, after the disintegration of the Ottoman Empire, already under the conditions of the new nation-states, after the First World War, this internal distinction disappeared relatively quickly under the new historical context, in which the Roma were placed. In Turkey, only Roma Muslims remained (the Roma Christians in their majority left Turkey in the population exchange after the Lausanne agreement). In the independent Balkan states, the significance of religious difference between Gypsies decreased at the expense of struggles for an ethnic unity.

Of course, the first steps in this direction are rather episodic, the deeds being of individual representatives of the community and without serious consequences for the community as a whole. However, this is also something to be expected, because this is precisely the general pattern of the development of nationalism in the region of Central, South-Eastern and Eastern Europe during the modern era, which has already been discussed in the preface to this book. According to the general pattern of the development of modern nationalism in the region, an integral part of which was also the movement for Roma civic emancipation, initially, a new, relatively small national elite emerged, spreading its ideas among the masses. For the Roma in the Balkans, under the Ottoman Empire, there is evidence only for the first phase of this pattern, an important component of which was the emergence of Romani literature and the Roma printed media. 